\title{
Application of Risk Management to the Level of Financial Efficiency in BPD JAWA TENGAH
}

\author{
Tito Cayadi Luthfan
}

University Singaperbangsa karawang

1810631030117@student.unsika.ac.id

\section{Gusganda Suria Manda \\ University Singaperbangsa karawang \\ gusganda.suriamanda@fe.unsika.ac.id}

\section{Suryanto Sosrowidigdo}

University Bina Sarana Informatika

suryanto.sys@bsi.ac.id

\begin{abstract}
Efficiency is one measure of bank performance. The efficiency of a bank is influenced by how management manages risk. This study measures the level of efficiency of conventional banking at PT Bank Pembangunan Daerah Jawa Tengah and the effect of financing risk, operational risk, and liquidity risk on the level of efficiency. Efficiency is measured by the Operational Expenditure method from Operating Income. The results of the calculation seen from the Operational Expenditure financial ratio report data from Operational Income show the level of efficiency of conventional banking at 80.65\% in 2015-2019. The data used as the object of this study is the Bank Pembangunan Daerah Jawa Tengah for the period 2015-2019. Based on the results of statistical tests and discussion analysis, it is known that financing risk, operational risk, liquidity risk together have a simultaneous effect on the level of efficiency PT. Bank Pembangunan Daerah Jawa Tengah. From the results of hypothesis testing it was found that financing risk has a significant positive effect on the level of bank efficiency, operational risk does not have a significant negative effect on efficiency, and liquidity risk does not have a significant positive effect on the level of efficiency at PT Bank Pembangunan Daerah Jawa Tengah. And this is also reinforced by a significance value of $0.003<0.05$ (numbers are taken from ANOVA), which means that there is a statistically significant influence between financing risk, operational risk, liquidity risk on the level of efficiency.
\end{abstract}

Keywords financing risk, operational risk, liquidity risk, Financial Efficiency

\section{INTRODUCTION}

Regional Development Bank (BPD) is a financial institution that is central to a region in realizing economic development (Afriyeni, 2019). The current banking conditions which are performing well are influenced by all BPDs in Indonesia (Nazir \& Mahfuzah, 2018). This is evidenced by the improvement in the performance and health of development 
banks in 2015. The average performance of Regional Development Banks reached 2.77\% which became the largest contributor to banking growth in Indonesia, which grew by around 25.7 percent when compared to the same period the previous year (Nazir \& Mahfuzah, 2018). The Regional Development Bank expects good performance in carrying out its role as an institution to improve the economy of local communities (Sitepu, 2017). This can be seen from the financial reports issued by the Regional Development Bank. The calculation of the ratios in the financial statements can be the basis for evaluating the performance of Regional Development Banks (SUHERTI \& Fernos, 2019). In order to improve performance for the better, Regional Development Banks need to implement risk management (Nazir \& Mahfuzah, 2018). This is the latest regulation issued by the Central Bank of Indonesia which asks every bank in Indonesia to form a risk management team. This team is obliged to control various aspects of risk management in each bank and to observe the impact of risk management implementation, especially on monetary strength in Indonesia(Yunita, 2018). The application of risk management is very important in the banking world in relation to the losses it experiences, as well as Regional Development Banks are expected to be able to detect the maximum losses that may arise in the future.(Eriza \& Afriyeni, 2019). These risks, such as credit risk, market risk, liquidity risk and operational risk, are often experienced by Regional Development Banks, and all of these risks are measured using ratio analysis tools. The application of risk management in Regional Development Banks, especially credit risk, the analysis tool used is the Non-Performing Loan (NPL), which is a comparison of nonperforming loans to total loans. A high NPL will disrupt the circulation of Regional Development Bank funds, causing Regional Development Banks to experience a decline in performance(Amalina \& Saifi, 2018). Measuring banking performance is also done by using the liquidity ratio, which is termed the Loan to Deposit Ratio (LDR), which is the ratio of loans to third parties and third party funds. The higher the LDR, the higher the bank's profit, with the increase in bank profit, the bank's performance also increases. LDR has an effect on banking performance. Furthermore, the application of risk management in this study used is the ratio of Operational Expenses to Operating Income (BOPO), which is to measure the ability of the Regional Development Bank management in controlling operational costs against operating income (Kansil et al., 2017). High BOPO indicates the inefficiency of Regional Development Banks in carrying out their operations, thus affecting the performance of Regional Development Banks (Nazir \& Mahfuzah, 2018). Bank Pembangunan Daerah Jawa Tengah was first established in Semarang based on the Approval of the Minister of General Government \& Regional Autonomy No. DU 57/1/35 dated March 13, 1963 and a business license from the Minister for Central Bank Affairs No. 4 / Kep / MUBS / 63 dated March 14, 1963 as the operational base for Central Java. The first operation started on April 6, 1963 by occupying the Bapindo Building, Jl. Hero No. 3 Semarang as the Head Office(Jateng, 2017)..

\section{LITERATURE REVIEW}

Efficiency is a fundamental concept and is born from the concept of economy. The level of bank efficiency is a measurement of how much the bank's ability to carry out its operational activities. The financial ratio used to measure the level of bank efficiency is BOPO (Operational expenditure to operating income), Operational expenditure is the profit sharing given to the customer and the profit sharing operating income obtained 
from the customer. The smaller the BOPO value means the more efficient banks operate(Hakiim, 2018).

Risk management is essentially a comprehensive process equipped with the tools, techniques and science necessary to identify, measure and manage risk in a more transparent manner. As a comprehensive process, risk management touches almost every aspect of a business entity's activities, from the decision-making process to invest a certain amount of money, to the decision to hire a new employee.(Suwinardi, 2016).

The purpose of risk management is to prevent or minimize the adverse effects resulting from unexpected events through avoiding risks or preparing contingency plans related to these risks(Senduk, Willar, \& Manoppo, 2016). The implementation of risk management in banks plays a very big role in increasing shareholder value through the implementation of risk-based business strategies. Risk management provides an overview to bank managers regarding potential losses in the future, as well as providing information to make the right decisions so that it can help bank managers to improve competitiveness(Mukhlishin \& Suhendri, 2018). Financing risk management or mitigation is carried out so that the financing risk does not exceed the limit level that has been set in accordance with the bank's risk appetite. Risk mitigation is carried out by referring to the financing policy, as the basis for banks to manage financing(Nazwirman \& Hasta, 2016).

NPF (Non performing financing) Bad credit is credit that is experiencing repayment difficulties due to deliberate factors or due to conditions beyond the ability of the debtor, which means that a debtor is unable to pay off his bill at the bank(fernos, 2019). A credit is said to be bad if it cannot meet the criteria for current, substandard and doubtful credit, can meet the criteria for doubtful credit, but after a period of 21 months since the credit management period is doubtful, there has been no repayment of the loan, or credit rescue efforts, Payment settlement back the credit concerned, has been submitted to the district court or the State Accounts Receivable Agency (BUPN), atau telah diajukan permintaan ganti rugi kepada perusahaan asuransi kredit(Malik Mahardika, 2012).

CAR (Capital Adequacy Ratio) Capital to Risk Weighted Assets Ratio (RWA), which reflects the Bank's capital adequacy to withstand the risk of losses that may be faced by the Bank, particularly credit risk, market risk and operational risk(Mandasari, 2015).

FDR (Financing to deposit ratio) The ratio between the total volume of credit extended by banks and the amount of funds received from various sources (Nurul Fitria dan Raina Linda Sari, 2012). Another definition of FDR is the financial ratio of a banking company related to the liquidity aspect. FDR is a traditional measurement that shows time deposits, current accounts, savings and others that are fulfilled in a customer's financing request(Suryani \& Ika, 2019)

\section{PROPOSED METHOD}

The theoretical framework is a reasoning framework that consists of concepts or theories as a reference for research (Nuroso \& Siswanto, 2012). Usually theoretical frameworks are arranged in the form of matrices, charts or simple drawings. The following is a quantitative research process which consists of several processes as described below: 


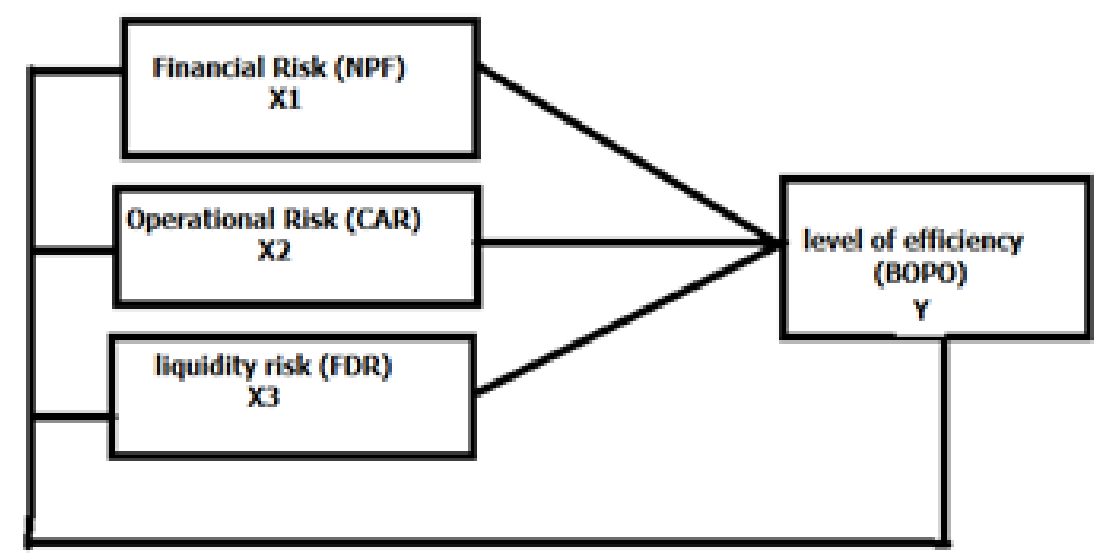

Figure 3.1. Theoretical Framework

In Figure 1. The approach used is quantitative with a descriptive format because it aims to explain and tell various situations and conditions, or various variables that are the object of the research based on what happened.

In this study will discuss the effect of financing risk (X1), operational risk (X2), liquidity risk (X3) on the level of efficiency (Y).

1. Literature review

Researchers study references in the form of books, journals related to risk management on the level of financial efficiency at the Bank, multiple linear regression to be used as a theoretical study in research..

2. Data collection

Population is a generalization area consisting of objects / subjects that have certain quantities and characteristics that are applied by research to study and then draw conclusions. So the population in this study is the Financial Quarterly (March, June, September and December) 2015-2019PT Bank Pembangunan Jawa Tengah(ojk.go.id, 2017).

The sample is part of the number and characteristics possessed by the population (Khasanah \& Pertiwi, 2010). In this study, the Quarterly financial reports (March, June, September and December) of the Bank Pembangunan Daerah Jawa Tengah for the period 2015-2019, for the financial reports in the March 2016 quarter were not issued which means there were 19 samples.

The operational definition is carried out to avoid deviations in discussing and analyzing the research problems carried out. The operational definition of the variables in this study is:

1) The dependent variable (dependent variable) is a variable whose value is influenced by other variables. The dependent variable of this study is the level of bank efficiency (Y). In this study the dependent variable is measured by Operational Expenditures from Operational Income (BOPO), namely the number of BOPO levels in PT Bank Pembangunan Daerah Jawa Tengah periode 2015-2019 obtained from Quarterly financial reports (March, June, September and December) PT Bank Pembangunan Daerah Jawa Tengah. 
2) The independent variable (independent variable) is a variable whose value does not depend on other variables. In this research, the independent variable is:

a. Financing risk (X1). What is meant by the risk of financing in this study is the number of NPF levels at PT Bank Pembangunan Daerah Jawa Tengah for the 2015-2019 period obtained from the quarterly financial reports (March, June, September and December) of PT Bank Pembangunan Daerah Jawa Tengah.

b. Operational risk (X2). Operational risk is defined as the total CAR level at PT Bank Pembangunan Daerah Jawa Tengah for the 2015-2019 period obtained from the quarterly financial reports (March, June, September and December) of PT Bank Pembangunan Daerah Jawa Tengah.

c. Liquidity risk (X3). What is meant by liquidity risk is the total FDR level at PT Bank Pembangunan Daerah Jawa Barat and Banten for the period 2015-2019 obtained from the Quarterly financial reports (March, June, September and December) of PT Bank Pembangunan Daerah Jawa Tengah.

This study uses quantitative data methods, where the data used in the study is in the form of numbers and calculations using statistical methods assisted by the SPSS 21 program. Data collection is sourced from the financial institution OJK (Financial Services Authority) for Publication reports at PT Bank Pembangunan Daerah Jawa Tengah Quarter (March, June, September and December) from 2015 to 2019.

Table 3.1. PT BPD Jawa Tengah Financial Report

\begin{tabular}{|c|c|c|c|c|c|}
\hline YEAR & $\begin{array}{l}\text { QUARTE } \\
\text { RLY }\end{array}$ & NPF & CAR & FDR & BOPO \\
\hline \multirow{4}{*}{2015} & MARCH & 0.98 & 14.96 & 72.07 & 69.25 \\
\hline & JUNE & 1.09 & 13.06 & 69.38 & 71.70 \\
\hline & $\begin{array}{l}\text { SEPTEM } \\
\text { BER }\end{array}$ & 1.22 & 12.70 & 70.34 & 74.06 \\
\hline & $\begin{array}{c}\text { DECEMB } \\
\text { ER } \\
\end{array}$ & 1.26 & 14.87 & 90.54 & 76.02 \\
\hline \multirow{4}{*}{2016} & MARCH & 0 & 0 & 0 & 0 \\
\hline & JUNE & 1.45 & 19.78 & 79.98 & 72.64 \\
\hline & $\begin{array}{c}\text { SEPTEM } \\
\text { BER }\end{array}$ & 1.50 & 19.78 & 77.33 & 72.32 \\
\hline & $\begin{array}{c}\text { DECEMB } \\
\text { ER }\end{array}$ & 1.45 & 20.25 & 95.05 & 76.18 \\
\hline \multirow{4}{*}{2017} & MARCH & 1.56 & 20.94 & 75.27 & 68.84 \\
\hline & JUNE & 1.61 & 19.93 & 77.06 & 73.54 \\
\hline & $\begin{array}{c}\text { SEPTEM } \\
\text { BER }\end{array}$ & 1.69 & 20.07 & 79.40 & 71.48 \\
\hline & $\begin{array}{c}\text { DECEMB } \\
\text { ER }\end{array}$ & 1.64 & 20.41 & 95.10 & 74.60 \\
\hline \multirow{4}{*}{2018} & MARCH & 1.83 & 18.61 & 81.95 & 68.40 \\
\hline & JUNE & 1.88 & 17.42 & 84.57 & 70.96 \\
\hline & $\begin{array}{c}\text { SEPTEM } \\
\text { BER }\end{array}$ & 1.84 & 17.35 & 87.31 & 69.25 \\
\hline & $\begin{array}{c}\text { DECEMB } \\
\text { ER }\end{array}$ & 1.03 & 18.31 & $\begin{array}{c}101.5 \\
7 \\
\end{array}$ & 73.87 \\
\hline
\end{tabular}




\begin{tabular}{|c|c|c|c|c|c|}
\hline \multirow{7}{*}{2019} & MARCH & 2.27 & 18.89 & 84.31 & 78.03 \\
\cline { 2 - 6 } & JUNE & 2.99 & 17.03 & 79.57 & 86.21 \\
\cline { 2 - 6 } & $\begin{array}{c}\text { SEPTEM } \\
\text { BER }\end{array}$ & 2.98 & 16.62 & 77.82 & 83.22 \\
\cline { 2 - 6 } & $\begin{array}{c}\text { DECEMB } \\
\text { ER }\end{array}$ & 2.88 & 17.70 & 9.29 & 80.65 \\
\hline
\end{tabular}

In Table 3.1.The reports published for the public are Quarterly from 2015 - 2019, with a note that there is no March 2016 Quarterly report, so the sample taken to process the data is $\mathrm{N}=19$.

3. Data analysis

Data analysis conducted by this study on these data is as follows :

a. Classic assumption test

The classical assumption test is used to obtain a regression model that produces the best unusual linear estimator or BLUE (Best Linear Un] Estimator). BLUE can be achieved if it fulfills the classical assumptions. In the classical assumption test research used is the normality test, multicolonierity test, heteroscedasticity test, autocorrelation test.(D y a h N i rm al a A rum Ja ni e, 2012).

b. Multiple Linear Regression Test

Multiple linear analysis is used to predict how the state (rise and fall) of the dependent variable, when two or more independent variables as predictor factors are manipulated (increase and decrease in value).

c. Hypothesis testing

Hypothesis testing includes:

1. Determinant Coefficient Test $\left(\mathrm{R}^{2}\right)$

The coefficient of determination is used to determine the percentage of the relationship between independent and dependent ariable. The large percentage of the effect of all variables on the dependent ariable value can be seen from the magnitude of the determinant coefficient $\left(\mathrm{R}^{2}\right)$ of the regression equation

2). Partial Test (Test t)

The $t$ test is used to test whether each independent variable (independent) individually or individually has a significant effect on the dependent variable (dependent) at a significant level of $0.05(5 \%)$ by assuming the independent variable is constant.

3). Simultaneous Test (Test f).

The $\mathrm{f}$ test is used to determine the effect of financing risk, operational risk and liquidity risk on the level of bank efficiency. The f test basically shows whether all the independent or free variables included in the model have a joint influence on the dependent or dependent variable. With the F table test criteria, if Fcount $<$ Ftable then $\mathrm{H}_{0}$ is accepted and $\mathrm{Ha}$ is rejected, it means that it is not significant and if Fcount> Ftable then $\mathrm{H}_{0}$ is rejected and $\mathrm{Ha}$ is accepted, it means that it is significant.

\section{RESULTS AND DISCUSSION}

following:

The discussion of the research results includes several tests, including the

1. Classic assumption test

The Classical Assumption Test consists of several tests, they are:

a. Normality test 
The normality test is one of the analysis requirements testing. What is meant here is the requirements that must be met in order for the analysis to be carried out, both for predictive purposes and for hypothesis testing purposes. This test is done to find out whether the population is normally distributed or not.

Table 4.1. Test results Normalitas One-

Sample Kolmogorov-Smirnov Test

\begin{tabular}{|c|c|c|}
\hline \multicolumn{3}{|c|}{ One-Sample Kolmogorov-Smirnov Test } \\
\hline & & $\begin{array}{l}\text { Unstandardized } \\
\text { Residual }\end{array}$ \\
\hline $\mathrm{N}$ & & 19 \\
\hline \multirow{2}{*}{$\begin{array}{l}\text { Normal } \\
\text { Parameters }\end{array}$} & Mean & 0,0000000 \\
\hline & $\begin{array}{l}\text { Std. } \\
\text { Deviation }\end{array}$ & 3,08072131 \\
\hline \multirow{3}{*}{$\begin{array}{l}\text { Most Extreme } \\
\text { Differences }\end{array}$} & Absolute & 0,163 \\
\hline & Positive & 0,093 \\
\hline & Negative & $-0,163$ \\
\hline Test Statistic & & 0,163 \\
\hline $\begin{array}{l}\text { Asymp. Sig. } \\
\text { tailed) }\end{array}$ & & $.197^{\mathrm{c}}$ \\
\hline \multicolumn{3}{|c|}{ a. Test distribution is Normal. } \\
\hline \multicolumn{3}{|c|}{ b. Calculated from data. } \\
\hline \multicolumn{3}{|c|}{ c. Lilliefors Significance Correction. } \\
\hline
\end{tabular}

Based on table 4.1. above, it can be seen that the value is 0.197 , so the value is greater than the significant value of 0.05 . So it can be concluded that the data is normally distributed.

b. Multicolonierity Test

Multicolonierity test is a test to determine whether or not there is a significant correlation between the independent variables in a multiple linear regression model. This test is needed to determine whether there are other variables in one model or not. The similarity between the independent variables in a model will cause a very strong correlation between an independent variable and other independent variables.

Table 4.2. Multicolonierity Test

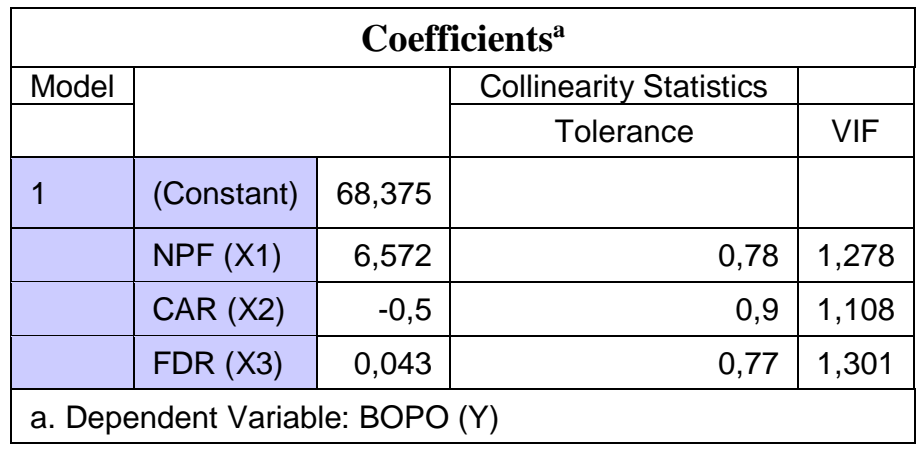


By the seen from table 4.2. it can be concluded that the Variance Inflation Factor value is 1.278 for the financing risk variable (NPF), 1.108 for the operational risk variable (CAR) and 1.301 for the liquidity risk variable (FDR) and the number of each variable < of 10, and the Tolerance value for the financing risk variable (NPF) 0.782 , for the operational risk variable (CAR) 0.903, and for the liquidity risk variable (FDR) 0.769. So for the variable financing risk, operational risk and liquidity risk and the number of each variable> than 0.1 , the model can be said to be free from multicollinearity.

c. Heteroscedasticity

TestHeteroscedasticity test is a condition where the variance of the confounding error is not constant for all values of the independent variable, where this test aims to test whether the regression model does not have similarities in variants of the residuals or other observations

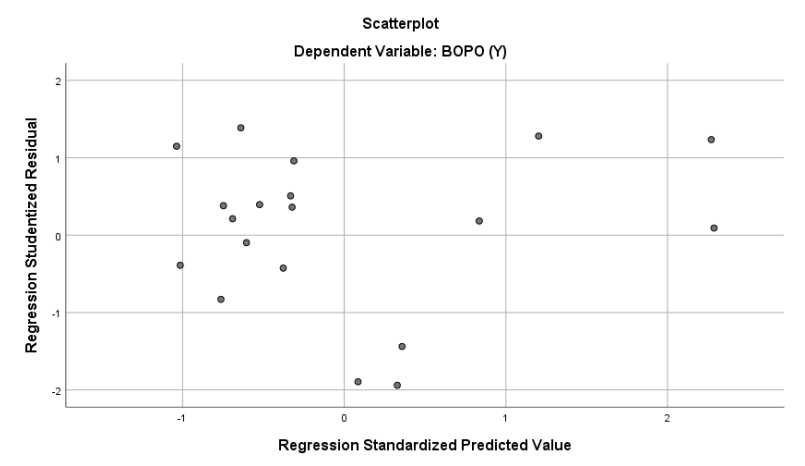

Figure 4.1. Scatterplot

From figure 2. the characteristics of the model scatterplot image are:

1) The data points spread over and below or around the 0 .

2) Data points don't just clump up or down.

3) The spread of data points should not form a wavy pattern that widens then narrows and throws back.

4) The distribution of data points should not be patterned.

So it can be concluded that the characteristics are met so that it can be said that in the regression model the effect of financing risk, operational risk and liquidity risk on the level of bank efficiency does not occur heteroscedasticity so that the classic assumption test of heteroscedasticity is fulfilled. then in this case it can be continued to the multiple linear regression test stage.

b. Autocorrelation Test

The autocorrelation test is used to see if there is a linear relationship or error in a series of observations that are sorted according to time (time series data). This test is carried out if the data being analyzed is time series data. To see if there is autocorrelation disease. The test that is often used is the Durbin-Waston test (DW test). In addition to using the Durbin-Waston test, the Breusch Goldfrey serial correlatiaon LM Test can also be used. The test steps are as follows:

Hypothesis

$\mathrm{H}_{0}$ :The model has autocorrelation

$\mathrm{H}_{\mathrm{a}}$ : The model does not have autocorrelation

If probability> Alpha (0.05), $\mathrm{H} 0$ is rejected, $\mathrm{H}_{\mathrm{a}}$ is accepted

If the probability <Alpha $(0.05), \mathrm{H}_{\mathrm{a}}$ is rejected, $\mathrm{H}_{0}$ is accepted 
Table 4.3. Autocorrelation Test

\begin{tabular}{|l|c|c|c|}
\hline \multicolumn{4}{|c|}{ Model Summary $^{\mathbf{b}}$} \\
\hline Model & $\mathrm{R}$ & $\begin{array}{c}\text { Std. } \\
\text { Error of } \\
\text { the } \\
\text { Estimate }\end{array}$ & $\begin{array}{c}\text { Durbin- } \\
\text { Watson }\end{array}$ \\
\hline 1 & $.777^{\mathrm{a}}$ & 3,37476 & 1,696 \\
\hline $\begin{array}{l}\text { a. Predictors: (Constant), FDR (X3), CAR } \\
\text { (X2), NPF (X1) }\end{array}$ \\
\hline \multicolumn{4}{|l|}{ b. Dependent Variable: BOPO (Y) } \\
\hline
\end{tabular}

From table 4.3. Autocorrelation test, for the value of du, we look for the durbin Watson table value distribution based on $\mathrm{k}(3)$ and $\mathrm{N}=19$ with a significance of $5 \%$, then du $(1,685)<$ Durbin Watson $(1,696)<4-\mathrm{du}(2,315)$ can concluded that there is no autocorrelation.

2. Multiple Linear Regression Test

Multiple linear analysis is used to predict how the state (rise and fall) of the dependent variable, when two or more independent variables as predictor factors are manipulated (increase and decrease in value).

Table 4.4. Multiple Linear Regression Test Results

\begin{tabular}{|c|c|c|c|c|c|}
\hline \multicolumn{6}{|c|}{ Coefficients $^{\mathbf{a}}$} \\
\hline \multirow[t]{2}{*}{ Model } & & & & \multirow{2}{*}{$\begin{array}{c}\text { Standardized } \\
\text { Coefficients }\end{array}$} & \multirow[t]{2}{*}{$t$} \\
\hline & & & & & \\
\hline 1 & (Constant) & 68,375 & 6,773 & & 10,1 \\
\hline & NPF (X1) & 6,572 & 1,441 & 0,838 & 4,56 \\
\hline & CAR (X2) & $-0,5$ & 0,339 & $-0,252$ & $1,48^{-}$ \\
\hline & FDR (X3) & 0,043 & 0,048 & 0,164 & 0,89 \\
\hline
\end{tabular}

From table 4.4. From calculations using SPSS, the following results are obtained:

$\mathrm{a}=68,375$

$\mathrm{b}=6,572$

$\mathrm{b} 2=-0,500$

b3 $=0,043$

Based on the multiple linear regression equation formula, the results of the analysis are as follows:

$$
\begin{aligned}
\mathrm{Y}= & 68,375+\{(6,572) \mathrm{X} 1+(-0,500) \mathrm{X} 2+ \\
& (0,043) \mathrm{X} 3\}
\end{aligned}
$$

The multiple regression equation model is significant:

The value of multiple linear regression analysis which is still in the form of numbers can be explained in easy-to-understand language as follows:

a) The $\alpha$ value of 68.375 means that if the variable risk of financing (X1) operational risk (X2) and liquidity risk (X3) is constant or does not change (equal to zero, then the level of efficiency (Y) will be worth 68.375. 
b) The regression coefficient value $\mathrm{X} 1=6,572$ shows that if the risk of financing has increased by $100 \%$ it will result in an increase in the level of efficiency at PT Bank Pembangunan Daerah Jawa Tengah by 6,572 .

c) The regression coefficient value $\mathrm{X} 2=-0,500$ indicates that if the risk of financing has increased by $100 \%$ it will result in an increase in the level of efficiency at PT Bank Pembangunan Daerah Jawa Tengah by $-0,500$.

d) The regression coefficient value X3 $=0.043$ indicates that if the risk of financing has increased by $100 \%$ it will result in an increase in the level of efficiency at PT Bank Pembangunan Daerah Jawa Tengah by 0.043 .

3. Hypothesis testing

a. Determinant Coefficient Test $\left(\mathrm{R}^{2}\right)$

The coefficient of determination is used to determine the percentage of the relationship between the independent variable and the dependent variable. The magnitude of the percentage effect of all variables on the value of the dependent variable can be seen from the determinant coefficient $\left(\mathrm{R}^{2}\right)$ of the regression equation. The coefficient of determination is seen from the results of the SPSS calculation as follows:

Table 4.5. Coefficient Test Results Determinan $\left(\mathrm{R}^{2}\right)$

\begin{tabular}{|c|c|c|}
\hline \multicolumn{3}{|c|}{ Model Summaryb } \\
\hline Model & $\mathrm{R}$ & R Square \\
\hline 1 & $.777^{\mathrm{a}}$ & 0,604 \\
\hline \multicolumn{3}{|c|}{$\begin{array}{l}\text { a. Predictors: (Constant), FDR (X3), } \\
\text { CAR (X2), NPF (X1) }\end{array}$} \\
\hline \multicolumn{3}{|c|}{ b. Dependent Variable: BOPO (Y) } \\
\hline
\end{tabular}

Judging from table 4.5. the determinant coefficient $\left(\mathrm{R}^{2}\right)$ shows the Adjusted $\mathrm{R}$ Square number of 0.604 or $60.4 \%$, which means that the variation in the level of efficiency can be explained by financing risk, operational risk and liquidity risk, the remaining $39.6 \%$ can be explained from other variables outside. of the research variables.

b. Partial Test (t test)

$t$ test is used to test whether each independent variable (independent) individually or individually has a significant effect on the dependent variable (dependent) at a significant level of $0.05(5 \%)$ by assuming the independent variable is constant.

Table 4.6. Partial Test Result (t test)

\begin{tabular}{|c|c|c|c|}
\hline \multicolumn{4}{|c|}{ Coefficients $^{\mathrm{a}}$} \\
\hline Model & & $\mathrm{t}$ & Sig. \\
\hline \multirow[t]{4}{*}{1} & (Constant) & 10,095 & 0 \\
\hline & NPF (X1) & 4,561 & 0 \\
\hline & CAR (X2) & $-1,475$ & 0,161 \\
\hline & FDR (X3) & 0,887 & 0,389 \\
\hline \multicolumn{4}{|c|}{ a. Dependent Variable: BOPO (Y) } \\
\hline
\end{tabular}


Judging from table 4.6. The partial test results can be seen by looking at the SPSS output coefficients results in the t-test above by comparing the $t$ count with the $t$ table of 2.131 obtained from the $t$ table with $\mathrm{df}=\mathrm{n}-\mathrm{k}$ (19-4) which is 15 and alpha 0.05 . To see partially, the effect of financing risk on the level of efficiency at PT Bank Pembangunan Daerah Jawa Tengah, then the analysis is as follows:

1) The effect of financing risk (X1) on the efficiency level (Y) of the hypothesis: $\mathrm{H}_{0}$ : partial financing risk has no significant effect on the efficiency level of PT Bank Pembangunan Daerah Jawa Tengah.

$\mathrm{H}_{\mathrm{a}}$ : the risk of financing partially has a significant effect on the efficiency level of PT Bank Pembangunan Daerah Jawa Tengah. Based on the results of the $t$ test for the financing risk variable, it was obtained tcount 4.561 and ttable 2.131 with a significant value of $0.000<0.05$, so $\mathrm{H} 0$ was rejected and $\mathrm{H}_{\mathrm{a}}$ was accepted. This indicates that the risk of financing has a partially significant effect on the level of efficiency of PT Bank Pembangunan Daerah Jawa Tengah.

2) The effect of operational risk (X2) on the efficiency level (Y) of the hypothesis: $\mathrm{H}_{0}$ : operational risk partially has no significant effect on the efficiency level of PT Bank Pembangunan Daerah Jawa Tengah. $\mathrm{H}_{\mathrm{a}}$ : operational risk partially has a significant effect on the efficiency level of PT Bank Pembangunan Daerah Jawa Tengah.

Based on the results of the $t$ test for operational risk variables, it is obtained tcount -1.475 and ttable 2.131 with a significant value of $0.161<0.05$, so $\mathrm{H}_{0}$ is accepted and $\mathrm{H}_{\mathrm{a}}$ is rejected. This shows that operational risk does not have a significant negative effect partially on the efficiency level of PT Bank Pembangunan Daerah Jawa Tengah.

3) The effect of liquidity risk (X3) on the efficiency level (Y) of the hypothesis: $\mathrm{H}_{0}$ : Partially liquidity risk has no significant effect on the level of efficiency of PT Bank Pembangunan Daerah Jawa Tengah. $\mathrm{H}_{\mathrm{a}}$ : liquidity risk partially has a significant effect on the efficiency level of PT Bank Pembangunan Daerah Jawa Tengah.

Based on the results of the $t$ test for the liquidity risk variable, it was obtained $\mathrm{t}$ count 0.887 and t table 2.131 with a significant value of $0.389<0.05$, then $\mathrm{H}_{0}$ was accepted and $\mathrm{H}_{\mathrm{a}}$ was rejected. This shows that the risk of financing is not partially significant effect on the level of efficiency of PT Bank Pembangunan Daerah Jawa Tengah.

c. Simultaneous Test (Test f)

The $\mathrm{f}$ test is used to determine the effect of financing risk, operational risk and liquidity risk on the level of bank efficiency. The f test basically shows whether all the independent or free variables included in the model have a joint influence on the dependent or dependent variable. With the F table test criteria, if Fcount <Ftable then $\mathrm{H}_{0}$ is accepted and $\mathrm{H}_{\mathrm{a}}$ is accepted, it means that it is not significant and if Fcount> Ftable then $\mathrm{H}_{0}$ is rejected and $\mathrm{H}_{\mathrm{a}}$ is accepted, it means that it is significant. 
Table 4.7. Partial Test Result (t test)

\begin{tabular}{|c|c|c|c|}
\hline \multicolumn{4}{|c|}{ ANOVA $^{a}$} \\
\hline Model & & $\mathrm{F}$ & Sig. \\
\hline 1 & Regression & 7,621 & $.003^{b}$ \\
\hline \multicolumn{4}{|c|}{ a. Dependent Variable: BOPO (Y) } \\
\hline
\end{tabular}

Judging from table 4.7. From the ANOVA test or F test, the Fcount value is 7.621> F table 2.131 with a significant level of 0.003 . Because the probability is significant, it is much smaller than 0.05 , so $\mathrm{H}_{0}$ is rejected and $\mathrm{H}_{\mathrm{a}}$ is accepted.

This shows that simultaneously which states that there is a significant influence of joint financing risk on the level of efficiency at PT Bank Pembangunan Daerah Jawa Tengah.

\section{CONCLUSIONS AND SUGGESTIONS Conclusion}

Based on the results of research and discussion in this study regarding the effect of financing risk, operational risk and liquidity risk on the level of efficiency, it can be concluded that: Financing Risk has a partially significant effect on the level of efficiency at PT Bank Pembangunan Daerah Jawa Tengah 2015-2019. This shows that $\mathrm{H}_{0}$ is rejected and $\mathrm{H}_{\mathrm{a}}$ is accepted, which means that the risk of financing has a significant effect on the efficiency level of PT Bank Pembangunan Daerah Jawa Tengah. From the NPF data of PT Bank Pembangunan Daerah Jawa Tengah 2015-2019, it fluctuates by $2.88 \%$ which means the level of efficiency also experienced a fluctuation of $80.65 \%$ which means it is not stable. Operational Risk has no significant negative effect partially on the level of efficiency at PT Bank Sumut Syariah at KCPSy Kota Baru Marelan for the period 20152019. This shows that $\mathrm{H}_{0}$ is accepted and $\mathrm{H}_{\mathrm{a}}$ is rejected, which means that operational risk does not have a significant negative effect on the level of efficiency at PT Bank Pembangunan Daerah Jawa Tengah. From the CARPT data for the Central Java Regional Development Bank 2015-2019 has fluctuated by 17.70\% which means the level of efficiency also fluctuates by $80.65 \%$ which means it is not stable. Liquidity risk does not have a partially significant positive effect on the level of efficiency at PT Bank Pembangunan Daerah Jawa Tengah 2016-2018. This shows that $\mathrm{H}_{0}$ is accepted and $\mathrm{H}_{\mathrm{a}}$ is rejected, which means that liquidity risk does not have a significant positive effect on the level of efficiency at PT Bank Pembangunan Daerah Jawa Tengah. From the FDRPT data of the Central Java Regional Development Bank 2015-2019, it fluctuates by $9.2 \%$ which means the level of efficiency also fluctuates by $80.65 \%$ which means it is not stable.

\section{Suggestion}

As for this study, the authors suggest several things, namely:

1. Penelitian ini diharapkan dapat berguna bagi seluruh bank Pembangunan Daerah sebagai masukan kepada manajemen perbankan Konvensional agar dapat mengelola risiko dalam rangka meningkatkan kinerja dan efisiensi perbankan konvensional.

2. Given the limitations and the many shortcomings the author has in this study, it is hoped that in future studies to further refine this research such as adding variables or 
other factors in analyzing the level of efficiency at PT Bank Pembangunan Daerah Jawa Tengah

\section{BIBLIOGRAPHY}

Afriyeni, A. (2019). Savings Product Marketing Activities At Pt. West Sumatra Regional Development Bank (Bpd) Padang Main Branch. https://doi.org/10.31219/osf.io/tf2bz

Amalina, A., \& Saifi, M. (2018). Analysis of the Accounting System for Providing Multipurpose Loans as an Effort to Minimize Non-Performing Loans. Jurnal Administrasi Bisnis, 60(2), 19-27.

D y a h N i rm al a A rum Ja ni e. (2012). Descriptive Statistics \& Multiple Linier Regression With Spss (A. Dr. Hj. Ardiani Ika S., S.E., M.M., Ed.). Semarang: Semarang University Press.

Eriza, A., \& Afriyeni, A. (2019). The Procedure for Crediting Pt. West Sumatra Regional Development Bank (Bpd). 1-19. https://doi.org/10.31219/osf.io/k2yrm

Jateng, B. (2017). Company Identity Brief History, Vision \& Mission, Identity. Bank Jateng. Retrieved from https://www.bankjateng.co.id/tentang-kami/hubunganinvestor/laporan-triwulan/profil-maturitas/

Kansil, D., Murni, S., Tulung, J. E., Risiko, P., Kansil, D., Murni, S., ... Roa, B. (2017). The Effect of Banking Risk on Financial Performance in 2013-2015 (Regional Development Banks throughout Indonesia). Jurnal EMBA: Jurnal Riset Ekonomi, Manajemen, Bisnis Dan Akuntansi, 5(3), 3508-3517. https://doi.org/10.35794/emba.v5i3.17581

Khasanah, I., \& Pertiwi, O. D. (2010). Analysis of the Effect of Service Quality to the Consumer Satisfaction of St. St. Elisabeth Semarang IMROATUL. Jurnal Khasanah Pertiwi, 12(2), 117-124.

Nazir, R., \& Mahfuzah, N. (2018). The Effect of Risk Management Implementation on Financial Performance Satisfaction at Regional Development Banks in Indonesia. Jurnal Visioner \& Strategis, 7(1), 41-50.

Nuroso, H., \& Siswanto, J. (2012). Integrated Ipa1 Module Development Model Based on Student Cognitive Development 1). Jurnal Penelitian Pembelajaran Fisika, 1(1), 35-46. https://doi.org/10.26877/jp2f.v1i1/april.106

ojk.go.id. (2017). otoritas jasa Keuangan.

Sitepu, N. I. (2017). Role Of Syariah Banks In Price Control (Analysis Study of Islamic Banking in Indonesia). Jurnal Perspektif Ekonomi Darussalam, 1(1), 55-74. https://doi.org/10.24815/jped.v1i1.6520

SUHERTI, E., \& Fernos, J. (2019). Ratio Analysis Against Financial Statements At Pt. West Sumatra Regional Development Bank. 1-15. https://doi.org/10.31227/osf.io/9zte8

Yunita, N. A. (2018). The Influence of the Application of Banking Risk Management and the Implementation of Internal Audit on Credit Lending Policy. At-Tasyri', X(1), 41-58. 